SONJA VUKOVIĆ-BOGDANOVIĆ

Laboratory for Bioarchaeology

Archaeology Department,

Faculty of Philosophy

University of Belgrade, Serbia

E-mail: sonja.vukovic@f.bg.ac.rs
904:59”652”(497.11)

COBISS.SR-ID 254098188

Original research article

Received: September $28^{\text {th }} 2017$

Accepted: October $31^{\text {st }} 2017$

\title{
ROMAN ARCHAEOZOOLOGY IN SERBIA: STATE OF THE DISCIPLINE AND PRELIMINARY RESULTS
}

\begin{abstract}
Roman archaeozoology is a relatively young discipline in Serbia. In the course of the 20th century only a few papers regarding animal remains from the Roman period sites in Serbia have been published, while in the past decade archaeozoology has gathered momentum in Serbia, and so did the Roman archaezoology. This paper reviews available (published and unpublished) archaeozoological data from Roman sites in Serbia, gives a short overview of research topics and also offers suggestions for future studies.
\end{abstract}

KEYWORDS: ARCHAEOZOOLOGY, ROMAN PERIOD, HISTORY OF RESEARCH, SERBIA.

\section{INTRODUCTION ${ }^{1}$}

Animal bones, along with ceramics, are among the most frequent finds in Roman sites in Serbia. Faunal remains have generally been ignored and at times not even collected in the field. The number of Roman sites with published archaeozoological data is incomparably smaller than the total number of excavated ones. This is the consequence of a lack of specialists - archaeozoologists, but also of the cultural-historical approach prevailing in Serbian archaeology, especially when historical periods are concerned. Archaeozoological studies of Roman sites in Serbia have traditionally been in

1 This article is the result of the project "Bioarchaeology of Ancient Europe-Humans, Animals and Plants in the Prehistory of Serbia” (III 47001) funded by the Ministry of Education, Science and Technological Development of the Republic of Serbia. a subaltern position compared to the studies of architecture, written sources, ceramic, iconographic and other finds. However, in the past decade, with the inclusion of Archaeozoology as subjects and modules in primary, master and $\mathrm{PhD}$ studies at the Department of Archaeology of the Faculty of Philosophy in Belgrade, several specialists in the field of archaeozoology have evolved, and as a consequence, archaeozoology has gathered momentum in Serbia and so did Roman archaeozoology, along with the recognition of the possibilities that archaeozoological studies open in the reconstruction and illumination of different aspects of life in Roman provinces in Serbia. This paper reviews the published archaeozoological data from Roman sites in Serbia, gives a short overview of research topics and also offers suggestions for future studies. 


\section{ROMAN ARCHAEOZOOLOGY IN SERBIA: HISTORY OF THE DISCIPLINE (FIG. 1)}

The first archaeoozoological papers in Serbia, that have come quite late when compared to the trends in Europe, referred to the mesolithic/neolithic site of Lepenski Vir and were published by S. Bökönyi (Bökönyi 1970, 1969), who was at the time the only specialist working in the region, mostly at prehistoric sites. However, the first Roman archaeozoological paper appeared even later and came from the late Roman site of Dumbovo in Vojvodina and was published by the same author (Bökönyi 1976). A large portion of archaeozoological data from Roman sites in Serbia came from Vojvodina region. During the last two decades of the 20th century Svetlana Blažić, a biologist from the Museum of Vojvodina in Novi Sad, was the only hired archaeozoologist in Serbia. From the Roman period sites, she has analyzed faunal remains from villa rustica at the site Vranj, near Hrtkovci (Blažić 1993), Roman layers of the site Gomolava, as well as the bones that had been collected during the rescue excavations of the highway route through Srem (sites Prosine, Prhovo; Prosine, Pećinci; Zlatara, Ruma; Kudoš, Šašinci; Livade, Sremska Mitrovica; Gajići, Adaševci; Mitrovačke Livade, Sremska Mitrovica) (Blažić 1995). These were mostly small settlements and villa remains, while the NISP was often very small. Dragana Nedeljković, a paleontologist hired by the Museum of Srem, has analyzed and reported on animal remains from the Roman city of Sirmium, which had been the capital of Late Roman Empire, from the sites of ,lokalitet 80 " (Nedeljković 1997) and ,lokalitet 85" (Nedeljković 2009), but also remains of horses from the hippodrome in Sirmium (Gilić 1994). Sirmium animal bones were also part of the PhD study of a Dutch archaeozoologist R. Lauwerier (Lauwerier 1978).

One of the biggest faunal collections in Serbia comes from the Roman site of Viminacium, containing animal bones that have been analyzed since 2009, by the author of this paper. Until now, animal remains have been analyzed from the area of the dump of the eastern necropolis (Vuković 2010) and the settlement and villas to the east from the city (the site called Nad Klepečkom) (Vuković - Bogdanović forthcomming), while the biggest assemblage comes from the Roman amphitheater and its surroundings (Vuković 2015, Vuković and Bogdanović 2013, Vuković 2011) the analyses of which are still in progress. Archaeozoological results of rescue excavations during protective excavations of the road E 75/E 80 in southern and eastern Serbia, from the late antique settlements at sites Davidovac-Gradište in southern Serbia (Miladinović-Radmilović, Vuković - Bogdanović, and Marković 2016) and Pirot-Sarlah basilica in eastern Serbia have also been analyzed. In Pirot, which used to be a road station in Roman times (Turres), faunal remains from the site called Pirot-Staro Vašarište where a high percentage of horse remains had been detected were also analyzed and made public (Vuković - Bogdanović and Pejić 2016). Another road station assemblage came from the nearby road station Timacum Maius at the site Niševac-Svrljig and was analyzed by I. Stojanović (Stojanović 2013). A small assemblage of animal remains from a tomb outside the 4th century palace Felix Romuliana (site Gamzigrad) was studied and the results published along with plant remains by V. Dimitrijević and A. Medović (Dimitrijević and Medović 2007). Animal bones that had been found within graves at the late Roman necropolis in Remesiana (eastern Serbia), among which chicken bones were predominant were described in a paper published by J. Jovanović and J. Bulatović (Јовановић and Булатовић 2013). Papers of S. Bökönyi, S. Blažić and D. Nedeljković mostly consist of the lists of identified animals and biometric data, while skeletal, age and sex profiles and also butchery patterns have become known only from recently published papers (Miladinović-Radmilović, Vuković - Bogdanović, and Marković 2016, Vuković - Bogdanović and Pejić 2016, Vuković 2015, 2010, Stojanović 2013) 


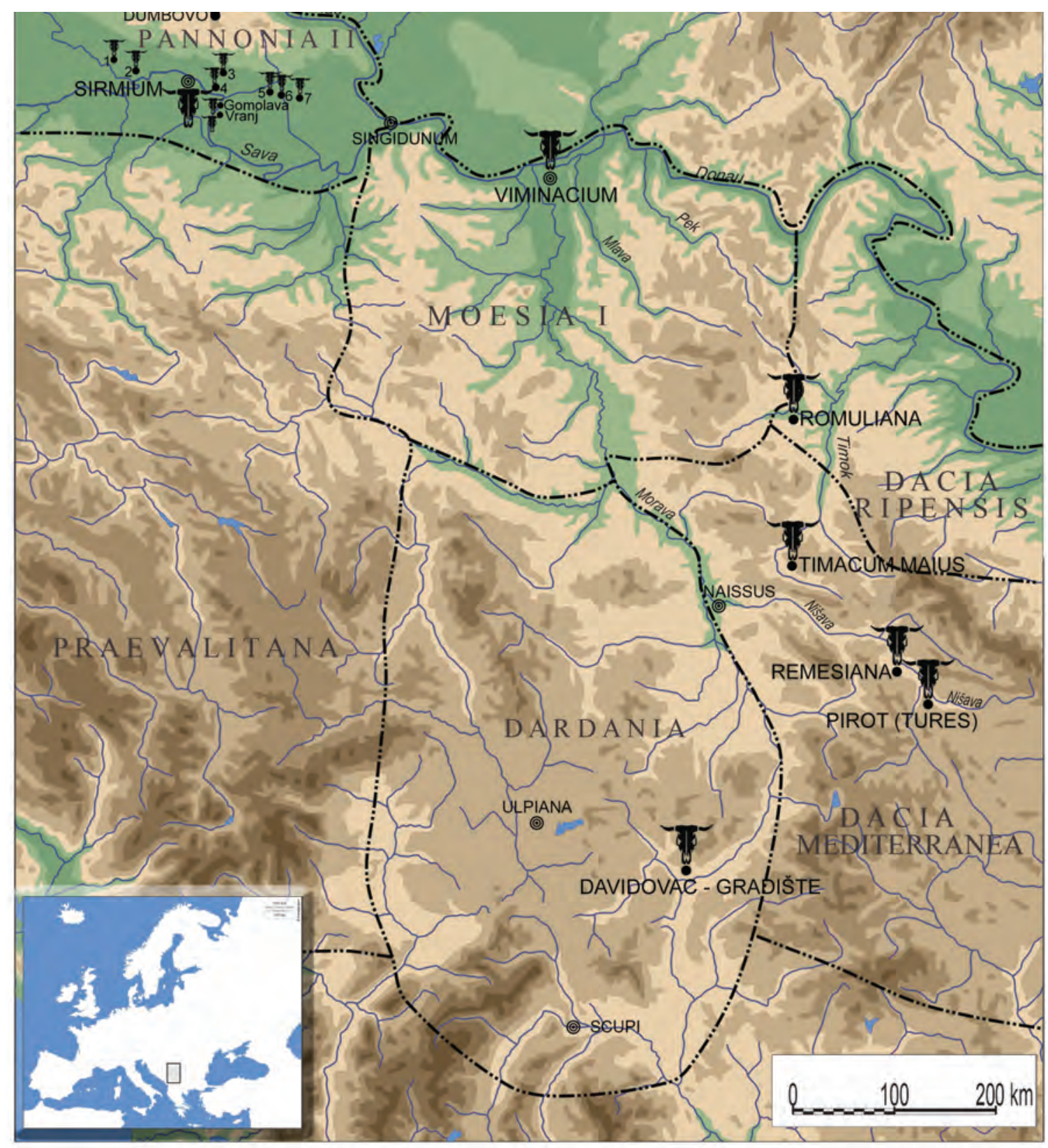

1.Gajići, Adaševci 2. Bregovi, Atovac, Kuzmin 3. Zlatara, Ruma 4. Kudoš, Šašinci 5. Prosine, Pećinci 6. Prosine, Prhovo 7. Malo Kuvalovo, Krnješevci

Fig. 1 The location of the sites with known archaeozoological data within the map of the Late Roman Provinces in the territory of Serbia.

\section{FAUNAL COMPOSITIONS AND DIETARY PATTERNS}

Animal remains from Roman period sites are often butchery and food waste, so by studying the composition of the most important meat providing animals (cattle, pig, sheep and goat), it is possi- ble to gain an insight into their general respective importance at different sites. For this reason, the presence of different animals in faunal assemblages, where NISP exceeds 450, was counted and the results compared (Table 1/Fig. 2). According to these data, cattle was the most important domestic animal in Roman provinces in Serbia. Cattle 


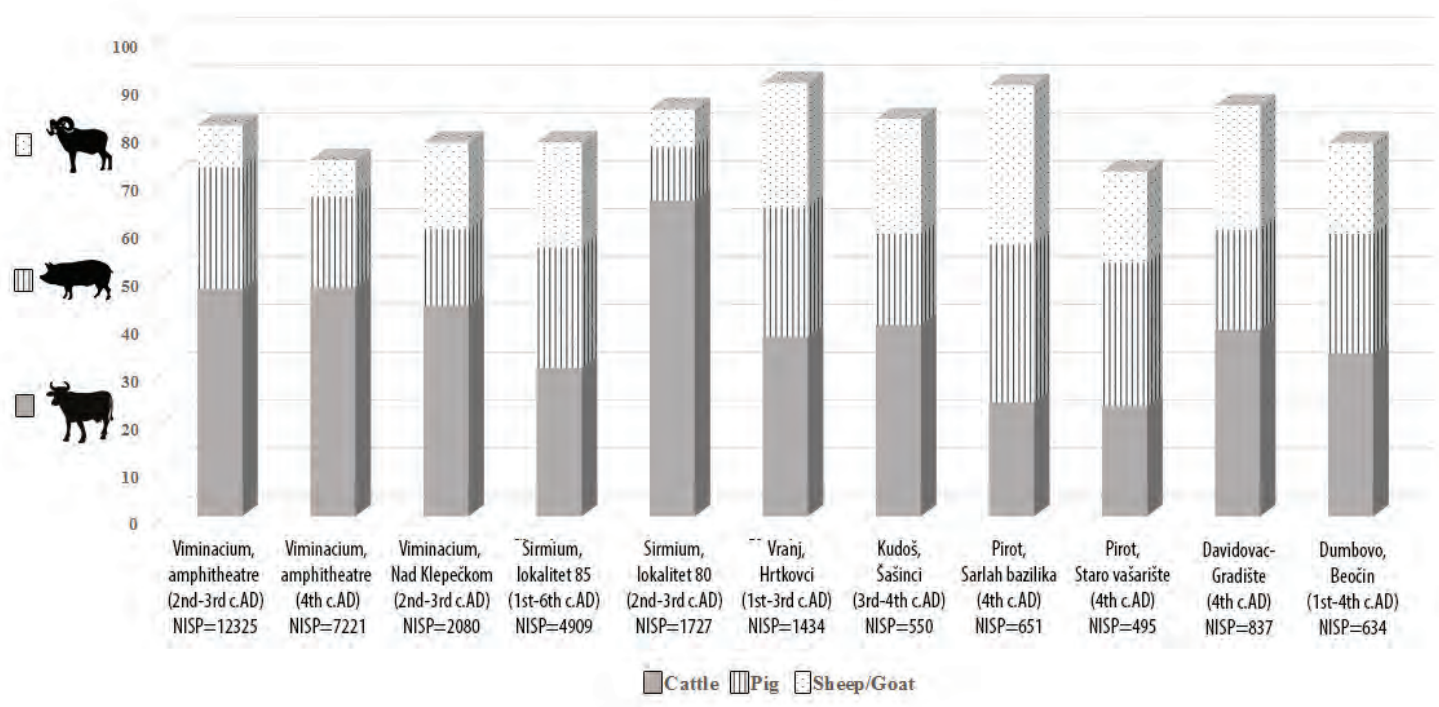

Fig. 2 Contribution of cattle, pig and sheep/goat remains (in percentages) from Roman period assemblages in Serbia, where NISP exceeds 450. Data taken from table 1.

remains prevail in relation to other domesticates at the majority of sites, while in Pirot (eastern Serbia) they are outnumbered by pigs and sheep/ goats. The highest importance of cattle, rising up to $40 \%$ and more, is noticed especially at urban sites (Sirmium and Viminacium), but also at other sites, villas and settlements. The second most common animals are either pigs or sheep/goats. Their importance is probably influenced by both environmental conditions, just as a higher percentage of sheep/goats is also observable in pastoral farming regions nowadays, but there are also cultural preferences. Cattle-dominant food pattern is observable at Romano-British sites, especially in towns and military assemblages, but sometimes also in Spain, France, Germany and other Danube provinces, while "typical” Roman food pattern is characterized by high percentages of pig bones (King 1999). Cattle were the most common animals in the periods that preceded Roman invasion in the territory of present-day Serbia, according to very few published data that mainly come from northern Serbia (Vojvodina) (Radišić 2016, Blažić 2006, 1992), so the continuity between the Iron Age and the Roman period is apparent.

Skeletal, age and sex profiles and butchery pat- terns were included only in recent papers and come mainly from Viminacium (Vuković - Bogdanović forthcomming, Vuković 2015, 2010), and also from Davidovac-Gradište (Miladinović-Radmilović, Vuković - Bogdanović, and Marković 2016) and sites in Pirot (Vuković - Bogdanović and Pejić 2016). Butchery patterns of domestic animals, especially of cattle, are in accordance with the same patterns that have been observed in urban settlements across the Empire (Maltby 2015, Maltby 2010, Lauwerier 1988, Peters 1998, Seetah 2006, 2004) and refer to butcher activities of specialists. Cutting and chopping marks made by both knives and cleavers, observed on cranial and postcranial bones, point to the skinning, disarticulating and filleting of animal corpses and also to meat preservation (i.e. perforated scapula blades) (Dobney, Jaques, and Irvig 1996). Split long bones and also a significant number of impact marks are remnants of marrow extraction (Fig. 3). Saw marks observed on antlers and horns, but also on long bones are indicative of bone working activities (Seetah 2006, 125). Cattle were mainly bred until adulthood, pigs were mostly slaughtered in juvenile age, and as for sheep and goats there is an equal ratio of both juvenile and adult animals. These data point 


\begin{tabular}{|c|c|c|c|c|c|c|c|}
\hline SITE & REFERENCE & NISP & $\begin{array}{c}\text { Cattle } \\
(\%)\end{array}$ & $\begin{array}{l}\text { Pig } \\
(\%)\end{array}$ & $\begin{array}{c}\text { Sheep/ } \\
\text { Goat } \\
(\%)\end{array}$ & $\begin{array}{c}\text { Game } \\
(\%)\end{array}$ & $\begin{array}{c}\text { Equids } \\
(\%)\end{array}$ \\
\hline $\begin{array}{l}\text { Bregovi, Atovac, Kuzmin } \\
\text { (4th-6th century AD) }\end{array}$ & Blažić 1995 & ? & 45.3 & 14.9 & 22.1 & 4.5 & 7.7 \\
\hline $\begin{array}{c}\text { Davidovac - Gradište (4th } \\
\text { century AD) }\end{array}$ & $\begin{array}{c}\text { Miladi- } \\
\text { nović-Radmi- } \\
\text { lović, Vukov- } \\
\text { ić-Bogdanović i } \\
\text { Marković } 2016\end{array}$ & 837 & 39 & 20.8 & 26 & 3 & 3,8 \\
\hline $\begin{array}{l}\text { Dumbovo, Beočin (1st-4th } \\
\text { century AD) }\end{array}$ & Bökönyi 1976 & 634 & 34 & 25 & 19 & 1.4 & 7,4 \\
\hline $\begin{array}{l}\text { Gajići, Adaševci (3rd-4th } \\
\text { century AD) }\end{array}$ & Blažić 1995 & 26 & 43.2 & 11.5 & 15.4 & 11.6 & 11.5 \\
\hline $\begin{array}{l}\text { Kudoš, Šašinci (3rd-4th } \\
\text { century AD) }\end{array}$ & Blažić 1995 & 550 & 40 & 19 & 24 & 4.4 & 10.5 \\
\hline $\begin{array}{c}\text { Livade, Sremska Mitrovica } \\
\text { (23) (3rd century AD) }\end{array}$ & Blažić 1995 & ? & 39.3 & / & 16.7 & 33.3 & 16.7 \\
\hline $\begin{array}{l}\text { Livade, Sremska Mitrovica } \\
\text { (26) (1st-3rd century AD) }\end{array}$ & Blažić 1995 & ? & 10.7 & I & 89.3 & / & l \\
\hline $\begin{array}{l}\text { Mitrovačke livade, Srems- } \\
\text { ka Mitrovica (4th century } \\
\text { AD) }\end{array}$ & Blažić 1995 & 142 & 54.9 & 8.2 & 19.7 & / & 16.2 \\
\hline $\begin{array}{c}\text { Niševac, Svrljig (2nd-4th } \\
\text { century AD) }\end{array}$ & Stojanović 2013 & 181 & 34.3 & 19.3 & 24.9 & 8.3 & 12.6 \\
\hline $\begin{array}{l}\text { Pirot, Sarlah bazilika (4th } \\
\text { century AD) }\end{array}$ & unpublished data & 651 & 23.8 & 32.9 & 33.3 & 1 & 2,8 \\
\hline $\begin{array}{l}\text { Pirot, Staro vašarište (4th } \\
\text { century AD) }\end{array}$ & $\begin{array}{l}\text { Vuković-Bog- } \\
\text { danović i Pejić } \\
2016\end{array}$ & 495 & 23 & 30 & 19 & 1.9 & 25 \\
\hline $\begin{array}{c}\text { Prosine, Pećinci (3rd-4th } \\
\text { century AD) }\end{array}$ & Blažić 1995 & ? & 43.5 & 11.3 & 19.4 & 11.3 & 6.5 \\
\hline $\begin{array}{c}\text { Prosine, Prhovo (3rd-4th } \\
\text { century AD) }\end{array}$ & Blažić 1995 & ? & 47.8 & 11.6 & 7.8 & 8.4 & 11.1 \\
\hline $\begin{array}{l}\text { Remesiana, Gladno Polje } \\
\text { (4th century AD) }\end{array}$ & $\begin{array}{l}\text { Jovanović and } \\
\text { Bulatović } 2013\end{array}$ & 50 & l & l & l & l & l \\
\hline $\begin{array}{c}\text { Romuliana, Gamzigrad } \\
\text { (3rd-4th century AD) }\end{array}$ & $\begin{array}{l}\text { Dimitrijević and } \\
\text { Medović } 2007\end{array}$ & 54 & I & l & I & l & l \\
\hline $\begin{array}{l}\text { Sirmium, lokalitet } 80 \\
\text { (2nd-3rd century AD) }\end{array}$ & $\begin{array}{c}\text { Nedeljković } \\
1997 \\
\end{array}$ & 1727 & 66 & 11 & 8 & 4 & 9,5 \\
\hline $\begin{array}{c}\text { Sirmium, lokalitet } 85 \text { (1st- } \\
\text { 4th century AD) }\end{array}$ & $\begin{array}{c}\text { Nedeljković } \\
2009 \\
\end{array}$ & 4909 & 31 & 25.1 & 22 & 4.6 & 2,5 \\
\hline $\begin{array}{l}\text { Viminacium, Pirivoj (2nd- } \\
\text { 3rd century) }\end{array}$ & Vuković 2010 & 419 & 25.1 & 12.9 & 6.7 & 0.7 & 2.4 \\
\hline $\begin{array}{l}\text { Viminacium, Amphitheater } \\
\text { (2nd-3rd century AD) }\end{array}$ & $\begin{array}{l}\text { Vuković } 2015, \\
\text { unpublished data }\end{array}$ & 12325 & 47.5 & 25.4 & 8.7 & 3 & 4.3 \\
\hline
\end{tabular}




\begin{tabular}{|c|c|c|c|c|c|c|c|}
\hline SITE & REFERENCE & NISP & $\begin{array}{c}\text { Cattle } \\
\mathbf{( \% )}\end{array}$ & $\begin{array}{c}\text { Pig } \\
\mathbf{( \% )}\end{array}$ & $\begin{array}{c}\text { Sheep/ } \\
\text { Goat } \\
\mathbf{( \% )}\end{array}$ & $\begin{array}{c}\text { Game } \\
\mathbf{( \% )}\end{array}$ & $\begin{array}{c}\text { Equids } \\
\mathbf{( \% )}\end{array}$ \\
\hline $\begin{array}{c}\text { Viminacium, Amphitheater } \\
\text { (4th century AD) }\end{array}$ & unpublished data & 7221 & 47.8 & 19 & 7.6 & 2.3 & 5.5 \\
\hline $\begin{array}{c}\text { Viminacium, Nad klepeč- } \\
\text { kom (2nd-3rd century AD) }\end{array}$ & $\begin{array}{c}\text { Vuković-Bog- } \\
\text { danović, in } \\
\text { preparation }\end{array}$ & 2080 & 44 & 16 & 18 & 0.3 & 10 \\
\hline $\begin{array}{c}\text { Vranj, Hrtkovci (1st-3rd } \\
\text { century AD) }\end{array}$ & Blažić 1993 & 1434 & 37.5 & 27 & 26 & 5.7 & 0,7 \\
\hline $\begin{array}{c}\text { Zlatara, Ruma (3rd-4th } \\
\text { century AD) }\end{array}$ & Blažić 1995 & $?$ & 45.1 & 7.8 & 16.7 & 11.8 & 11.8 \\
\hline
\end{tabular}

Table 1 List of Roman period sites in Serbia (in alphabetical order) with known archaeozoological data and references. The table also includes NISP (Number of identified specimens) for each site (if known) and also contributions of the cattle, pig, sheep/goats, equids and game. Unpublished data come from the reports/documentation of the author of the paper.

to the modes of animal keeping (adult specimens were used for secondary products: milk, wool and traction, while juvenile animals were killed for meat), but also to diet preferences as meat of adult cattle had obviously been consumed.

Meat was also acquired from domestic fowl, but in smaller quantities. Contribution of bird remains is cca $2-4 \%$ in faunal assemblages in Roman sites in Serbia (Vuković 2015, Nedeljković 2009, 1997, Blažić 2006). The most common birds are chicken, while occasionally bones of domestic goose and domestic duck are also found.

There are suggestions that horses were sometimes, in smaller quantities, eaten too (Vuković 2015). Butchering marks, observed on equid remains from Viminacium, point to skinning, but also dismembering and filetting activities. However, no special butchery patterns exist on equid remains, such as on other livestock bones, so those animals were probably not systematically butchered.

\section{HUSBANDRY PRACTICES}

One of the most common and conspicuous feature of animal keeping and breeding in Roman times is improved husbandry. The appearance of very large cattle, sheep and goats throughout Roman provinces that is evidenced by biometric analyses of animal remains is also testified by Roman sites in Serbia. During the late Iron age cattle wither heights reached the lowermost point (106-109) cm in the region (Blažić 2006, Radišić 2016), while at Roman sites wither heights range from 100 to $140 \mathrm{~cm}$ (Blažić 2006, Vuković 2015, Nedeljković 2009, 1997), which suggest the presence of small "local" breeds and also of improved breeds of cattle. The wither heights of sheep reach up to $82 \mathrm{~cm}$, while for goats they go up to $73 \mathrm{~cm}$ (Blažić 2006, Vuković 2015, Nedeljković 2009, 1997), so these results are also in accordance with the presence of improved Roman livestock.

The increase of cattle size is linked to the Roman acquisition and has been evidenced throughout Europe (Lauwerier 1988, Maltby 2016, Grau-Sologestoa 2015, Peters 1998, Audoin-Rouzeau 1993). It is usually explained by the import of large breeds from other provinces (mainly Italy), and their crossbreeding with local breeds, but also by import of new foodstuffs and selection of specific local breeds (Bökönyi 1974, Albarella, Johnstone, and Vickers 2008, MacKinnon 2010, Grau-Sologestoa 2015). However, improved breeds of cattle enabled a wide range of new advantages, such as an increased quantity of meat which was a necessity due to the growth of the cities and the population in them, but also greater strength of traction animals. 


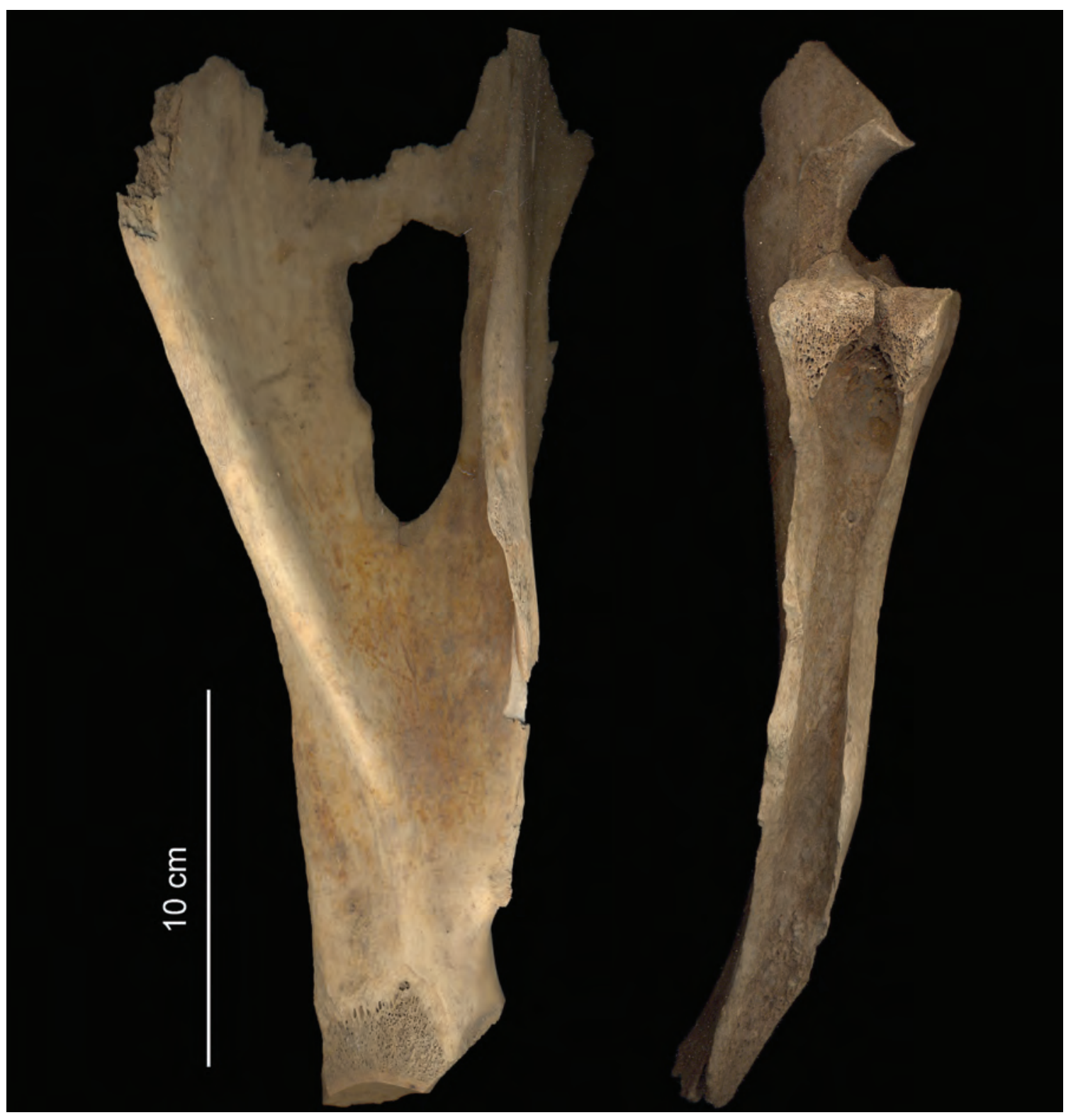

Fig. 3 Butchery marks on cattle scapula and radius and ulna from Viminacium amphitheater (Vuković 2015).

\section{HUNTING AND FISHING}

A minor percentage of wild fauna was quite common in Roman times - and this also refers to Serbian sites. The percentage varies between 0.5 and $6 \%$. The most frequent animal is the red deer, while roe deer, wild boar, hare, wolf, fox are also present (Blažić 2006, Nedeljković 2009, 1997, Vuković 2015). A significant number of brown bear remains has been reported from the area of the Viminacium amphitheater (Vuković 2015, 2011), which is probably related to the participa- tion of these animals in Roman games.

Animal bones at Roman sites were collected by hand, so there is a bias in the recovery of small and fragile bones, such as fish and bird remains. However, as a small percentage of fish has been detected, the settlers of Roman provinces probably did not significantly rely on fish resources. Among fish, there are remains of local freshwater fish (cyprinids, catfish, pike, perch, etc.) (Nedeljković 2009, 1997, Blažić 2006), but also of large migratory beluga fish (Vuković 2015). 


\section{PACK AND DRAUGHT ANIMALS}

The most common animals that have been used for transport ever since the time they had been domesticated are horses. Horse and donkey remains are common in Roman sites in Serbia, while the presence of their hybrids, mules, has been hypothesized according to morphometric features in Viminacium (Vuković 2015), Romuliana (Dimitrijević and Medović 2007) and Pirot (Roman Turres) (Vuković-Bogdanović and Pejić 2016). Mules were highly valued animals in Roman times and they were mostly used as pack animals, for drawing vehicles - civilian and official for the State post (cursus publicus) (Toynbee 1973: 185-192). Since there had been no previous attempts by archaeozoologists to identify mules, their presence can be hypothesized at other sites, too. Improved stock breeding was also evidenced on horse skeletal remains from Roman times in Serbia, where confirmation was found of the presence of smaller, probably autochthonous, horses with wither heights from 122 to $133 \mathrm{~cm}$ and improved Roman horses, with wither height between 142 and $150 \mathrm{~cm}$ (Miladinović-Radmilović, Vuković - Bogdanović, and Marković 2016, Vuković-Bogdanović and Pejić 2016, Vuković 2015, 2010, Nedeljković 2009, 1997, Gilić 1994, Blažić 2006, 1995).

The contribution of equid remains in faunal assemblages from Roman cities and settlements generally amounts to $2-4 \%$; in villas it is slightly higher as it reaches up to $10 \%$, while one site, Pirot-Sarlah basilika, stands out with its unusually high contribution of equid bones $-25 \%$. The site is located within the modern city of Pirot in eastern Serbia, which has been associated with the Roman road station Mansio Turres, mentioned in Roman itineraries. It is suggested that equid remains from the site are actually the remains of animals that had been bred for the road station (as pack animals for the transport of post and goods), or that they had been bred for the army unit that had probably been stationed in the vicinity of the site (Vuković - Bogdanović and Pejić 2016).
Besides horses, cattle, primarily oxen, were also used for transportation, as it is depicted on numerous monuments and mentioned in ancient texts (Toynbee 1973: 149-162). Pathological alternation on cattle bones that have been studied on Sirmium assemblage were linked to the usage of those animals for transport and draught (Marković et al. 2014). Camels, whose remains have also been attested in Roman sites in Serbia, were also used as pack animals (see section "Exotics”).

\section{ANIMALS AS PETS}

As nowadays, the most common pets in Roman times were cats and dogs. Domestic cat and dog remains are common in Roman sites in Serbia, too. According to wither heights of dogs from Roman sites in Serbia that span from 23 to $74 \mathrm{~cm}$ (according to Harcourt 1974), different breeds of dogs existed in the region, the smallest, probably toy dogs and also, bigger ones, that were kept not only as pets, but also as shepherd and hunting dogs (Blažić 2006, Vuković 2015, Nedeljković 2009, 1997).

\section{EXOTICS}

The most common "exotic" animal within sites throughout the Roman world is the camel. Camel remains in Serbia have been found in big cities, such as Viminacium and Sirmium, but also within smaller settlements and villas along the main roads (Vranj-Hrtkovci, Davidovac-Gradište, Pirot-Sarlah bazilika) (Vuković-Bogdanović and Blažić 2014). According to morphometric analyses of the bones, it is suggested that the bones belonged to hybrids of one- and two-humped camels and also two-humped camels. They were used as beasts of burden in Roman times (Toynbee 1973: 137-140), either for military use, for carrying equipment, or for civilian use. The fragmented skeleton of a hybrid camel (Fig. 4) found in the layers that buried the arena of Viminacium amphitheatre (Vuković 
and Bogdanović 2013) is the only camel skeleton in European sites throughout the Empire.

"Exotics" include also mollusk remains, mostly Mediterranean shells, such as oyster shells that had probably been imported as luxurious food, and murex snails that were used for pigment extraction in antiquity (Vuković 2015, Nedeljković 2009, 1997, Blažić 2006). Exceptionally, there are also finds of exotic shells, such as Cyprea tigris, Cyprea pantherina and Pinctada margaritifera. Mediterranean shells were sometimes found as grave goods, mostly in graves of women and children (Spasić-Đurić 2015b, 51, 2015a).

\section{ANIMALS IN RITUAL AND FUNERARY CONTEXTS}

It is generally very difficult to recognize ritual behavior in archaeological remains and therefore by interpreting special deposits of animal bones it is even more intricate to make a distinction between ritual deposits and food refuse or butchery waste. However, several researchers (eg. Groot 2009, Morris 2008, Grant 1984a, b) introduced certain criteria for the identification of ritual in animal bone assemblages, such as "association of one or more individuals, difference in butchery patterns, association with other finds", etc. (Groot 2009, 117). Several deposits of animal bones from Viminacium have been linked to ceremonies. These include dog burials, based on the bones found inside human graves or isolated, burials with grave goods, as, for instance, a burial of a young dog of a small breed with two ceramic lamps (Fig. 5). A skeleton of a skinned dog and a structural deposition of a dog buried together with a horse's skull, both from eastern Viminacium necropolis, were interpreted as offerings to chthonic gods (Vuković and Jovičić 2015). Such a deposition (a dog's skeleton and a horse's skull) has also been discovered underneath the entrance to the amphitheater, and is believed to be a foundational deposit - the remnant of a ritual that was in the connection with the construction of the amphitheater (Vuković 2015). A skeleton of a male horse of improved breed that had been buried beneath a human grave at the late Roman necropolis at the site Davidovac-Gradište near Vranje (Miladinović-Radmilović, Vuković-Bogdanović and Marković 2016) is the only published Roman horse burial within the region. Several horse burials have been reported from the southern necropolis of Viminacium (site „Više grobalја“) (Зотовић, Јордовић 1990), but, unfortunately, that was within earlier excavations of the site when no proper archaeozoological analyses were executed and the bones were discarded. Animal bones as grave goods are known only from the late Roman necropolis in Remesiana - where chicken bones were interpreted either as food offerings or offerings to deities (Јовановић, Булатовић 2013).

\section{CONCLUSION}

Although there are not many surveys of archaeozoological material from Roman sites in Serbia, especially in view of the number of excavated sites, previous and especially recent analyses enable at least understanding of animal exploitation, consumption of animals and their products and other human-animal interrelationships in the Roman provinces on the territory of present-day Serbia, whose overview has been presented in this paper.

There is an urgency to analyze new assemblages, and also to continue working on the material the analyses of which are in progress. New data will enable us to look into the diachronic perspectives on animal husbandry and meat diet in Roman provinces in Serbia, and also to compare different aspects of animal usage between different types of sites: urban, military, rural, etc. Research questions regarding food production (where food was produced and who produced it) might also be opened by new data. Isotopic analysis and genetic studies, the most promising and popular researches in present day archaeology, could improve the insight into 


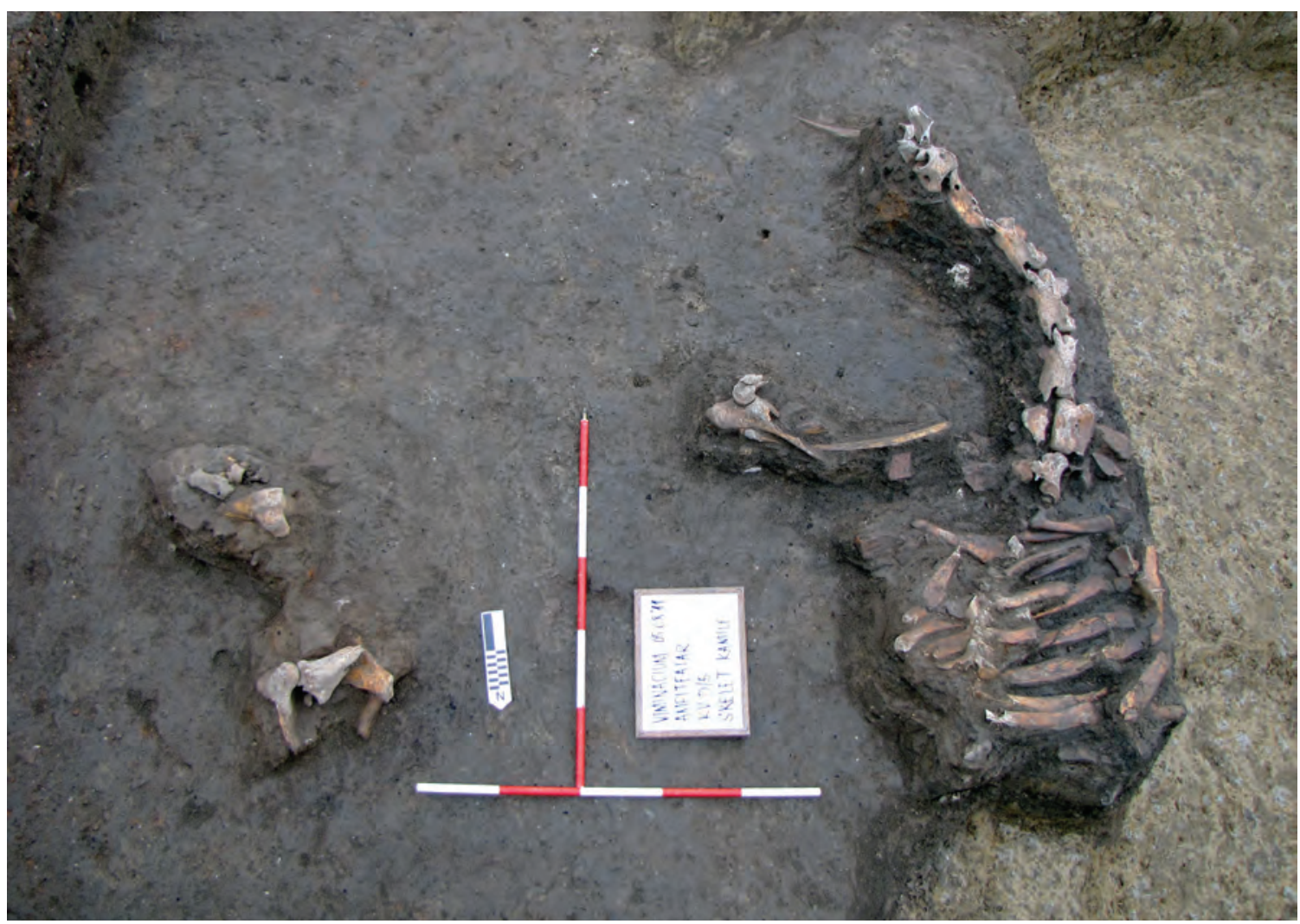

Fig. 4 Fragmented camel skeleton from Viminacium amphitheater (Vuković and Bogdanović 2013).

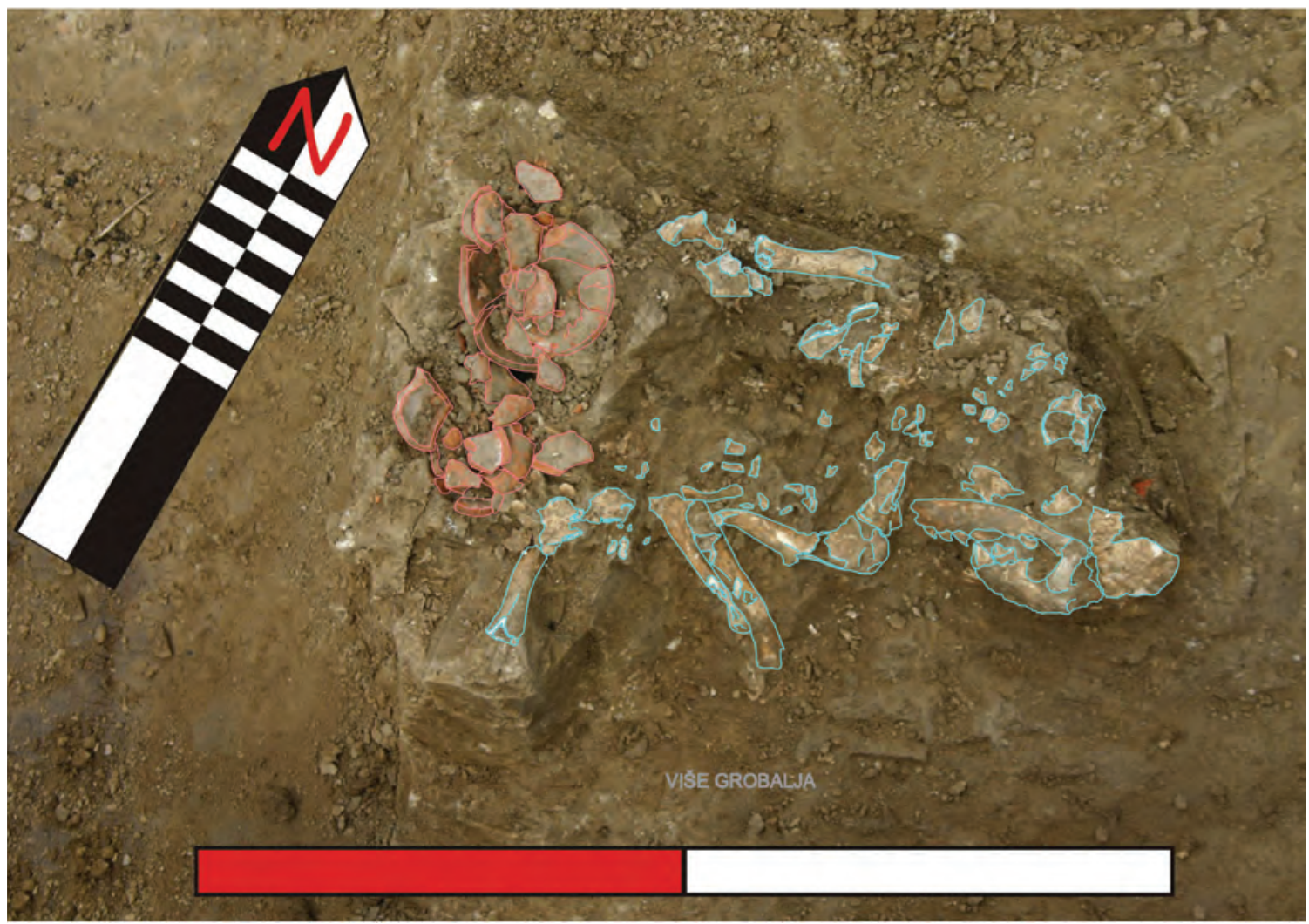

Fig. 5 A dog burial with two terracota lamps from the southern necropolis of Viminacium (after Vuković-Bogdanović and Jovičić 2015, drawing by Željko Jovanović ) 
the origin, migrations and diet of animals that lived in Balkan provinces of the Roman Empire.

\section{BIBLIOGRAPHY}

Albarella, U., Johnstone, C. and Vickers, K. 2008

The development of animal husbandry from the Late Iron Age to the end of the Roman period: a case study from South-East Britain, Journal of Archaeological Science 35: 1828-1848.

\section{Audoin-Rouzeau, F. 1993}

Hommes et animaux en Europe de l'époque antique aux temps modernes: Corpus de données archéozooloqiues et historiques. Vol. 16, Dossier de documentation archéologique, Paris: Centre National de la Recherche Scientifique.

\section{Blažić, S. 1992}

Faunal remains in Celtic fortresses and indigenous settlements, Balcanica XXIII: 401-406.

\section{Blažić, S. 1993}

Ostaci životinja sa lokaliteta Vranj 1991, Rad Muzeja Vojvodine 35: 71-78.

\section{Blažić, S. 1995}

Ostaci životinjskih vrsta sa lokaliteta na trasi auto-puta kroz Srem, u: Arheološka istraživanja duž auto-puta kroz Srem, Z. Vapa, (ed.), Novi Sad: Pokrajinski zavod za zaštitu spomenika kulture: 331-346.

\section{Blažić, S. 2006}

Fauna arheoloških lokaliteta u Vojvodini, Novi Sad: Muzej Vojvodine.

\section{Bökönyi, S. 1969.}

Kičmenjaci (prethodni izveštaj), u: Lepenski Vir Nova praistorijska kultura u Podunavlju, D. Srejović, (ed.), Beograd: Srpska književna zadruga, 224-228.
Bökönyi, S. 1970

Animal Remains from Lepenski vir, Science 167: 1702-1704. doi: 10.1126/science.167.3926.1702.

\section{Bökönyi, S. 1974}

History of Domestic Mammals in Central and Eastern Europe, Budapest: Akadémiai Kiadó.

\section{Bökönyi, S. 1976}

Ostaci životinjskih kostiju u Dumbovu - lokalitetu u Fruškoj gori iz rimskog carskog perioda, Građa za proučavanje spomenika kulture Vojvodine 6-7: 49-51.

\section{Dimitrijević, V, and Medović, A. 2007}

Animal and plant remains in a tomb in test-pit $1 / 05$, outside the fortified imperial palace Felix Romuliana, Старинар 59: 315-323.

Dobney, K., Jaques, D. and Irvig, BG. 1996 Of butchers \& breeds: report on vertebrate remains from various sites in the city of Lincoln, Lincoln Archaeological Studies, Lincoln: City of Lincoln Archaeology Unit.

\section{Gilić, D. 1994}

Ostaci konja (Equus caballus L.) sa arheološkog lokaliteta Hipodrom u Sirmijumu, Rad

Muzeja Vojvodine 36: 81-94.

\section{Grant, A. 1984a}

Animal husbandry, in: Danebury: an Iron Age hillfort in Hampshire. The excavations 19691978. Volume 2: the finds, E. Cunliffe, (ed.), London: Council for British Archaeology: 102-119.

\section{Grant, A. 1984b}

Survival or sacrifice? A critical appraisal of animal burials in Britain in the Iron Age, in: Animals and archaeology 4, C. Grigson and J. Clutton-Brock, (eds.), Oxford: Oxford Archaeopress, 221-227.

\section{Grau-Sologestoa, I. 2015}

Livestock management in Spain from Roman to 
post-medieval times: a biometrical analysis of cattle, sheep/goat and pig, Journal of Archaeological Science 54: 123-134.

Groot, M. 2009

Animals in ritual and economy in a Roman frontier community: excavations in Tiel-Passewaaij, Amsterdam: Amsterdam University Press.

\section{Harcourt, R. 1974}

The dog in prehistoric and early historic britain, Journal of Archaeological Science 1: 151-175.

\section{King, A. 1999}

Diet in the Roman world: a regional inter-site comparison of the mammal bones, Journal of Roman archaeology 12: 168-202.

Lauwerier, R. 1988

Animals in Roman times in the Dutch eastern river area, Nederlandse Oudheden 12, Amersfoort: Rijksdienst voor het Oudheidkundig Bodemonderzoek.

\section{Lauwerier, R. 1978.}

Dieren in Sirmium, Unpublished PhD Thesis, University of Groningen.

\section{MacKinnon, M. 2010}

Cattle 'breed' variation and improvement in Roman Italy: connecting the zooarchaeological and ancient textual evidence, World Archaeology 42 (1): 55-73.

\section{Maltby, M. 2015}

Commercial Archaeology, Zooarchaeology and the Study of Romano-British Towns, in: The Towns of Roman Britain: the Contribution of Commercial Archaeology since 1990, M. Fulford and N. Holbrook, (eds.), London: The Society for the Promotion of Roman Studies: 175-193.

\section{Maltby, M. 2016}

The exploitation of animals in Roman Britain, in: The Oxford Handbook of Roman Britain, M. Millett, L. Revell and A. Moore, (eds.), Oxford: Oxford University Press.

Maltby, M. 2010

Feeding a Roman town: environmental evidence from excavations in Winchester, 1972-1985, Winchester: Winchester Museums and English Heritage.

Marković, N, Stevanović, O., Nešić, V., Marinković, D., Krstić, N., Nedeljković, D., Radmanović, D. and M. Janeczek. 2014

Palaeopathological study of Cattle and Horse bone remains of the Ancient Roman city of Sirmium (Pannonia / Serbia), Revue de Médecine Vétérinaire 165 (3-4): 77-88.

Miladinović-Radmilović, N, Vuković - Bogdanović, S. and Marković, N. 2016

Davidovac - Gradište: Rezultati preliminarnih bioarheoloških analiza osteološkog materijala. Davidovac - Gradište: Results of the preliminary bioarchaeological analyses of the the osteological material, u: Arheološka istraživanaj na autoputu E75 (2011-2014). Archaeological Investigations along the Highway Route E75 (2011-2014), Slaviša Perić and Aleksandar Bulatović, (eds.), Beograd: Arheološki institut: 351-382.

\section{Morris, J. 2008.}

Re-examining Associated Bone Groups from Southern England and Yorkshire, c.4000BC to AD1550, Unpublished $\mathrm{PhD}$ thesis, Bournemouth University.

\section{Nedeljković, D. 1997}

Ostaci životinjskih kostiju sa lokaliteta 80 Sirmijuma (1996.g.). Preliminarni izveštaj, Zbornik Muzeja Srema 3: 37-45.

\section{Nedeljković, D. 2009}

Pregled arheozooloških istraživanja Sirmijuma lokalitet 85 (2002-2005), Zbornik Muzeja Srema 8: 7-42. 


\section{Peters, J. 1998}

Römische Tierhaltung und Tierzucht: eine Synthese aus archäozoologischer Untersuchung und schriftlich-bildlicher Überlieferung: Leidorf.

\section{Radišić, T. 2016}

Životinje u ekonomiji latenskog naselja na nalazištu “Stari Vinogradi” u Čurugu, Arhaika 4: 63-84.

\section{Seetah, K. 2004}

Meat in History - The Butchery trade in the Romano-British period, Food and History 4: 21-31.

Seetah, K. 2006. Butchery as an Analytical Tool: A Comparative Study of the Romano-British and Medieval Periods, Unpublished $\mathrm{PhD}$ thesis, University of Cambridge.

Spasić-Đurić, D. 2015a

Grad Viminacijum, Požarevac: Narodni muzej Požarevac.

\section{Spasić-Đurić, D. 2015b}

Значај и функција љуштура пужева Cypraea tigris и $C$. pantherina у римским гробовима у Горњој Мезији. Meaning and function of shells of Cypraea tigris and C. pantherina snails in Roman graves in Upper Moesia, Zbornik Narodnog muzeja XXII - 1: 259-277.

\section{Stojanović, I. 2013}

Ostaci životinja sa lokaliteta Niševac - Timacum Maius kod Svrljiga, Etno-kulturološki zbornik XVII: 19-25.

\section{Toynbee, J. M. C. 1973}

Animals in Roman life and art, Baltimore and London: Thames \& Hudson.

Vuković- Bogdanović, S, and Blažić, S. 2014 Camels from Roman Imperial sites in Serbia, Anthropozoologica 49 (2): 281-295.
Vuković - Bogdanović, S. forthcomming

Animal remains from the site Nad klepečkom (settlement in the vicinity of the city of Viminacium).

Vuković - Bogdanović, S. i Pejić, P. 2016

Konji, magarci i mule iz rimske putne stanice Mansio Turres. Horses, donkeys, and mules from the Roman road station Mansio Turres, Arhaika 4: 85-103.

\section{Vuković, S. 2010}

Ostaci životinja sa jugozapadnog dela lokacije Pirivoj (Viminacijum), Arheologija i prirodne nauke 5: 57-82.

\section{Vuković, S. 2011}

Medved u rimskom spektaklu. Studija slučaja amfiteatra u Viminacijumu. (Bear in Roman spectacle, Viminacium amphitheater case study), Glasnik Srpskog arheološkog društva 27: 315- 338.

\section{Vuković, S. 2015.}

Životinje u rimskim afiteatrima. Studija slučaja amfiteatra u Viminacijumu, Neobjavljena doktorska disertacija, Filozofski fakultet, Univerzitet u Beogradu.

\section{Vuković, S. and Bogdanović, I. 2013}

A Camel Skeleton from the Viminacium Amphitheatre, Starinar 63: 251-267.

\section{Vuković, S. and Jovičić, M. 2015}

Dog Burials from the Cemeteries of the Roman City of Viminacium (Moesia Superior, Kostolac, Serbia), in: LIMES XXII. Proceedings of the 22nd International Congress of Roman Frontier Studies. Ruse, Bulgaria, September 2012., L. Vagalinski and N. Sharankov, (eds.), Sofia: National Archaeological Institute with Museum Bulgarian Academy of Sciences: 687-702.

Зотовић, Љ. и Јордовић, Ч. 1990

Viminacium 1. Некропола Више гробаља, Београд: Археолошки институт; Републички 
завод за заштиту споменика.

Јовановић, Ј. и Булатовић, J. 2013

Домаћа кокошка (Gallus domesticus) у погребном ритуалу на Ремезијани, u: Bioarheologija na Balkanu. Bilans i perspektive, Miladinović-Radmilović, N. and Vitezović, S. (eds.), Beograd: Srpsko arheološko društvo/ Blago Sirmiuma: 161-171.

\section{REZIME RIMSKA ARHEOZOOLOGIJA U SRBIJI: STANJE DISCIPLINE I PRELIMINARNI REZULTATI}

\section{KLJUČNE REČI: ARHEOZOOLOGIJA, RIMSKI PERIOD, ISTORIJAT ISTRAŽIVANJA, SRBIJA.}

Životinjske kosti, uz keramiku, na većini antičkih lokaliteta u našoj zemlji, predstavljaju najzastupljenije nalaze. Ostaci faune dugo su bili zanemarivani, a postoje lokaliteti na kojima se još uvek ne sakupljaju. Broj antičkih nalazišta u Srbiji, sa publikovanim arheozoološkim podacima, nesrazmerno je manji u odnosu na broj istraženih nalazišta. To je, pre svega, rezultat nedostatka stručnog kadra, ali i kulturnoistorijskog pristupa, koji je prisutan u srpskoj arheologiji, pogotovo u antičkoj arheologiji. Arheozoološke studije sa antičkih nalazišta u našoj zemlji uglavnom su zauzimale podređeni položaj u odnosu na proučavanje arhitekture, antičkih izvora, keramičkih nalaza i predstava na spomenicima. Intenzivniji razvoj srpske arheozoologije, a samim tim i rimske arheozoologije, primetan je u poslednjih desetak godina, zahvaljujući uvođenju kurseva iz arheozoologije na osnovnim, master i doktorskim akademskim studijama arheologije na Filozofskom fakultetu u Beogradu, odnosno zahvaljujući mogućnosti obrazovanja i usavršavanja arheologa u oblasti arheozoologije.

Najveći broj publikovanih rezultata faunističke analize potiče sa teritorije Vojvodine. Veliki do- prinos analizi faune arheoloških lokaliteta Vojvodine dala je S. Blažić iz Muzeja Vojvodine, koja je obradila faunu iz villae rusticae na lokalitetu Vranj kod Hrtkovaca (Blažić 1993), rimske slojeve Gomolave, ostatke životinja, koji su prikupljeni prilikom zaštitnih iskopavanja na trasi autoputa kroz Srem (Blažić 1995). Faunom Sirmijuma bavi se D. Nedeljković, koja je obradila materijal sa „lokaliteta 80“ (Nedeljković 1997) i „lokaliteta 85“ u Sirmijumu (Nedeljković 2009), kao i ostatke konja sa sirmijumskog hipodroma (Gilić 1994). Ostatke faune rimskog naselja u Dumbovu kod Beočina analizirao je Š. Bekenji (Bökönyi 1976). Najveća faunistička zbirka potiče sa lokaliteta Viminacijum, gde ostatke životinja analizira autorka rada. Do sada su analizirani ostaci životinja sa prostora istočne gradske nekropole (Vuković 2010) i naselja i vila, koji su istraženi istočno od grada (lokalitet Nad klepečkom) (Vuković-Bogdanović forthcomming), dok najveći uzorak, čije analize su u toku, potiče sa prostora amfiteatra i njegovog okruženja (Vuković 2015, Vuković and Bogdanović 2013, Vuković 2011). Životinjske kosti analizirane su i na nalazištima rimskog perioda, u okviru zaštitnih istraživanja na trasi Koridora 10, i to na lokalitetima Pirot-Sarlah Bazilika i Davidovac-Gradište (Miladinović-Radmilović, Vuković - Bogdanović, and Marković 2016). U Pirotu, gde je ubifikovana putna stanica Mansio Turres, potiče faunistička zbirka, koja se izdvaja visokim udelom ekvida (Vuković - Bogdanović and Pejić 2016). Sa lokaliteta Niševac-Svrljig, u čijoj blizini se nalazila još jedna putna stanica, Timacum Maius, ostatke životinja analizirala je I. Stojanović (Stojanović 2013). Na lokalitetu Gamzigrad (Felix Romuliana) obrađeni su ostaci životinja iz grobnice, koja je otkrivena van zidina Romuliane (Dimitrijević and Medović 2007). Na kasnoantičkoj nekropoli inhumiranih pokojnika u Remezijani, analizirani su ostaci životinja, koji su pronađeni kao prilozi u grobovima, što predstavlja jedinu studiju ovog tipa na rimskim nalazištima u Srbiji (Јовановић and Булатовић 2013).

Dominantna vrsta $u$ većini faunističkih zbir- 
ki sa rimskih nalazišta u Srbiji je goveče, pogotovo $\mathrm{u}$ većim urbanim centrima (Viminacijum $\mathrm{i}$ Sirmijum), te se može pretpostaviti da je meso ovih životinja najčešće korišćeno $u$ ishrani. $\mathrm{Na}$ drugom mestu po zastupljenosti nalaze se ostaci svinja ili ovaca i koza, što je, verovatno, uslovljeno i prirodnim okruženjem, kao i kulturnim odabirom. Razvijeno stočarstvo, kao jedna od osnovnih odlika gajenja životinja u rimsko doba, a koje se pretpostavlja na osnovu biometrijskih karakteristika ekonomski najznačajnijih životinja, uočeno je i na rimskim nalazištima u Srbiji, gde se javljaju sitne, lokalne rase, kao i krupne, unapređene rase goveda, ovaca i koza. Ekvidi: konji, magarci i njihovi hibridi - mule, čine uobičajeni deo faunističkih zbirki, a može se zaključiti da su ove životinje prevashodno korišćene za transport i prenos tereta. Za prenos tereta korišćene su i kamile, koje su uvođene širom provincija, a čiji ostaci su pronalaženi na većem broju nalazišta u Srbiji uz glavne puteve. Osim kamila, od egzotičnih vrsta pronađene su ljušture mediteranskih školjki i puževa, koje se često mogu naći u ljudskim grobovima. Psi i mačke, koji su u velikom broju pronalaženi na rimskim nalazištima u Srbiji, korišćeni su pre svega kao kućni ljubimci. Lov nije imao veliki ekonomski značaj, budući da ostaci divljih životinja, čine zanemarljiv udeo u rimskim faunističkim zbirkama u Srbiji. Od di- vljih sisara, pronađeni su u najvećem broju ostaci jelena, ali i srndaća, divljih svinja, zečeva, vukova i lisica, dok je na prostoru viminacijumskog amfiteatra pronađen veći broj kostiju mrkog medveda, što se dovodi u vezu sa namenom ovog objekta. Poput lova, ni ribolov nije imao značajniju ulogu u ishrani stanovnika rimskih provincija na tlu Srbije, a uglavnom su pronalaženi ostaci slatkovodnih dunavskih riba, kao i krupnih, migratornih riba moruna. Poneki konteksti sa životinjskim ostacima, kao što su sahrane pasa sa prilozima, ili u okviru ljudskih grobova, kao i kombinovani depoziti (lobanja konja i skelet psa), povezani su sa ritualnim aktivnostima, koje su praktikovane u rimskim provincijama na tlu Srbije.

Buduća istraživanja, koja se odnose na rimsku arheozoologiju u Srbiji, trebalo bi pre svega fokusirati na analizu materijala sa lokaliteta, iz kojih ne postoje arheozoološki podaci. Sa većim brojem nalazišta, sa obrađenim kostima, biće moguće otvoriti nova istraživačka pitanja, kao što su dijahroničko posmatranje ishrane, ekonomije i stočarstva, razlike u obrascima ishrane između različitih tipova nalazišta (gradska, seoska, vojna) i dr. Primenom najaktuelnijih analiza u arheologiji, genetičkih analiza i analiza stabilnih izotopa, biće moguće proširiti saznanja o poreklu, ishrani i migracijama životinja u rimskim provincijama na tlu Srbije. 